\title{
Over-Education in China
}

\author{
Ke Gao, Yifan Wang, Pengqiu Zheng \\ School of Government, Beijing Normal University, Beijing, China \\ Email: kk1206@sina.com
}

How to cite this paper: Gao, K., Wang, Y. F., \& Zheng, P. Q. (2017). Over-Education in China. Chinese Studies, 6, 37-43. https://doi.org/10.4236/chnstd.2017.61005

Received: January 12, 2017

Accepted: February 21, 2017

Published: February 24, 2017

Copyright ( $) 2017$ by authors and Scientific Research Publishing Inc. This work is licensed under the Creative Commons Attribution International License (CC BY 4.0).

http://creativecommons.org/licenses/by/4.0/

\begin{abstract}
Over education is not only happening in the Western countries. Since the enrollment of Chinese universities, the incidence of over-education has been significantly improved, and the study of over-education has been promoted. This paper begins with the definition of over-education, and combs the relevant research on over-education in the 1930s. It introduces the methods of over-education commonly used in China, the incidence of over-education, the impact of over-education on income. This paper also analyzes the problems of over-education.
\end{abstract}

Keywords

Over-Education, Incidence Rate, Income Effect

\section{Introduction}

According to the American educational sociologist Martin Trow proposed the development of the national higher education stage: the gross enrollment ratio of higher education is $15 \%$ bellow for the elite education stage, $15 \%-50 \%$ for the mass education stage, while for the general education stage is more than $50 \%$. In 1999, the State Council approved the "Plan for the 21st Century Education Revitalization" proposed in 2010 to enter the mass education stage, while in fact, China's higher education gross enrollment rate has reached 15\% in 2002, which means ahead of entering to the mass education stage. Over the years, the controversy over the expansion of Chinese universities has been discussed: some believe that we should control the expanding enrollment and focus on improving the quality of education as after years of college enrollment, and the scale of higher education has been excessive; while others think that although the scale of higher education in our country has been greatly developed in recent years, there still needs much development for expansion of education as compared to both in terms of the world average and the inherent requirements of its own economic and social development, and there is still a long way to go for China. Therefore, 
the excessive scale means that supply exceeds demand of labor in the labor market, which will not only result in a lower wage rate, but also lead to taking lower position for highly educated person.

On one hand, over-education will result in dissatisfaction with the work, thus affecting the productivity of workers. On the other hand, if the over-education is lasting a long time, it will also lead to the waste of educational resources. So what is the status quo of education in China? Does it have over-education in reality?

\section{The Status Quo of Over-Education in China}

\subsection{The Definition and Measurement Methods}

Whether a society is over-educated or not and the extent of over-education is large or small are closely related to the definition of over-education. The over-education is the most widely defined by Duncan and Hoffman's research in 1981: if "the level of individual education" is higher than "the level of education required for work", it is defined as over-education; otherwise is under-education; while if "the level of personal education" is equal to "work required education", it is the matched education. Bishop made an assumption that over-education will result in work dissatisfaction, occupational mobility, low productivity and political dissatisfaction; under education will limits economic growth (Bishop, 1993). So whether it is over-education or under education are the performances of education dis-matched and inefficient allocation of education.

There are three commonly used measures for over-education: job analysis, worker self-assessment and realized games. Wei Xin et al. conducted a sample survey, which in the degree of education (Wei Xin \& Qin Wanshun, 1990). They based on the fact of the enterprise, with reference to some of the domestic job knowledge and ability and seek the views from the relevant personnel to defined the education required by work. This method is similar to the analysis method, but also makes the research results are very limited, which cannot be compared with other research results. Li Fengliang et al. used the stratified cluster survey of the employment status of college graduates in 2003 (Li Fengliang, Yue Changjun, \& Hou Longlong, 2009), which adopted the most extensive self-assessment method, and the questionnaire survey was conducted by using the Peking University's "Higher Education Scale Expansion and Graduates Employment". But in fact there are problems that the possibility of graduates stay in the company that they internship is less, so it is impossible to make an accurate judgment on the level of education required for work, so it is also not reliable for make absolute accurate result of the study, but since this is a systematic deviation, it can still be compared with other similar studies. Wu Xiangrong et al. also adopted a self-assessment approach (Wu Xiangrong \& Lai Desheng, 2010), but they chose two more rigorous evaluation methods, from the employer and the individual staff point of view to assess the level of education required for work. As employers tend to develop higher access thresholds, the incidence of overwork has a downward bias; subjective judgments from the employee's point of view will underestimate the ability requirements of the post, so the results will have up- 
ward bias. And after Stasz's comparison of the two approaches, the level of skill required for employee evaluation is more accurate than the employer. The realized matches refers to the determination of the appropriate education is based on the average or the mode of workers' average education years in the occupation. Ma Wenwu et al. determinate the average education years with the realized methods and mode (Ma Wenwu \& Li Zhongqiu, 2016), which based on the characteristics that proved with the data of CHNS. Specifically, the author analysis the major jobs that involving 12 major types of industries and one cannot be classified in other occupations. Secondly, in order to reflect the dynamic characteristics of over-education changed over time, this paper tested these data to measure the status of over-education with stages of years, which are divided into one with these are similar at time, less change of economic and social environment. This measurement will increase the reliability compared with the single test of a year.

In addition, there are many other studies on the measurement of over- education is the use of qualitative description which mainly summarized from the employment rate of graduates over the years, the human capital stock in the sectors of the various regions, defined that China does exist over-education.

\subsection{Incident Rate of Over-Education}

The results of the study on the incidence rate of over-education in China are less. Table 1 shows the results of the study (Wu Xiangrong, 2007a). He used the sample data of the income distribution of the Chinese Academy of Social Sciences to estimate the incidence of over-education in different industries in

Table 1. Sample distribution on over-education in different industries.

Unit: \%

\begin{tabular}{|c|c|c|c|c|}
\hline & Entirety & Appropriate Education & Over-education & Under Education \\
\hline Agriculture Animal Husbandry and Fishery & 100 & 65 & 15.6 & 21.6 \\
\hline Manufacturing Industry & 100 & 67.3 & 13.8 & 19 \\
\hline Mineral Resource and Geological Exploration & 100 & 76.8 & 11.4 & 14 \\
\hline Architecture Industry & 100 & 65 & 10.2 & 25.9 \\
\hline Transmutation and Communication & 100 & 66.3 & 12.2 & 21.2 \\
\hline Commercial Trade/Catering and Warehousing Industry & 100 & 63.6 & 15.9 & 20.1 \\
\hline Real Estate and Public Utilities & 100 & 61.6 & 11.9 & 27.9 \\
\hline Health, Sports and Social Welfare & 100 & 62.3 & 11.4 & 26.5 \\
\hline Education, Culture and Art & 100 & 65.9 & 15.4 & 18.5 \\
\hline Scientific Researching and Technique Service & 100 & 67.8 & 20.4 & 10.9 \\
\hline Finance and Insurance Industry & 100 & 65 & 20 & 12.8 \\
\hline Government Institutions and Social Organizations & 100 & 58.7 & 26.6 & 14.3 \\
\hline
\end{tabular}

Data sours: Over-education Phenomenon and Its Income Effects, Xiangrong Wu, Journal of Beijing Normal University, 2007(3). 
China. We can see that the under education is more serious than the over-education in China's various industries, scientific research and technical services, financial and insurance industries are face with over-education as the industrial specificity for highly payment. It cannot reveal the required skills that a job or occupation needs for, as this study uses model methods(similar to realized matches)to collect the modes match to the work or occupation required education, besides it is not enough to measure from the job demand side.

The following Table 2 is the study which uses the data of the National College Graduates' Sampling Survey conducted by Peking University's “Higher Education Scale Expansion and Labor Market” Task Group in June 2003 (Yang Juan, Meng Dahu, \& Yue Changjun, 2011), which used workers' self-assessment method to measure over-education and found that the higher education is more likely to be over-educated; when they observe the impact of gender on excessive education found out the proportion of women over-education higher than men and the higher the academic qualifications, which is similar to Western Europe and the United States. Wu Xiangrong et al. to use the National Social Science Fund major project "to implement the expansion of employment development strategy research" task group in 2008 on the Beijing party and government agencies and enterprises and institutions of the employment situation survey data analysis, and analysis of the results are similar to Yang Juan's, that is, the higher the degree of education, the higher the degree of over-education.

\subsection{The Impacts on Income to Educational Level and Job Dismatching}

$\mathrm{Wu}$ Xiangrong studied the national income distribution survey data of the 1995 collected by the Income Allocation and reform Research Group of CASS (Wu Xiangrong, 2007b), found the variables of China's individual gender, length of service, work experience and personal career, the nature of the business are particular influence the return of over-education, after they control these variables found the followings: 1) the return on education required for work is higher than the actual education return, which indicating that the level of individual education and the allocation of work can affect the return on education; 2) the

Table 2. Incident rate on educational level and job dismatching.

\begin{tabular}{cccccccc} 
& \multicolumn{1}{c}{} & & & Unit: \% \\
\hline & \multicolumn{2}{c}{ Entirety } & \multicolumn{2}{c}{ Male } & \multicolumn{2}{c}{ Female } \\
\cline { 2 - 7 } Educational level & $\begin{array}{c}\text { Over } \\
\text { Education }\end{array}$ & $\begin{array}{c}\text { Under } \\
\text { Education }\end{array}$ & $\begin{array}{c}\text { Over } \\
\text { Education }\end{array}$ & $\begin{array}{c}\text { Under } \\
\text { Education }\end{array}$ & $\begin{array}{c}\text { Over } \\
\text { education }\end{array}$ & $\begin{array}{c}\text { Under } \\
\text { education }\end{array}$ \\
\hline College degree & 12.9 & 41.1 & 13.5 & 41.4 & 12.3 & 40.8 \\
Bachelor degree & 21.1 & 12.4 & 21.9 & 13.3 & 19.7 & 10.7 \\
Master degree & 35.8 & 7.3 & 36.9 & 6.4 & 34.1 & 8.5 \\
PhD degree & 42 & -- & 41.1 & 0 & 44.4 & 0 \\
Sum & 20.5 & 17.4 & 21.5 & 17.2 & 18.8 & 17.7 \\
\hline
\end{tabular}

Data: Empirical Research on the Investments and Returns on Higher Education. Juan Yang, Dahu Meng, Changjun Yue, Renmin University of China Education Journal, 2011(3). 
return on education is positive and less than the return of education required for work; 3) the under education is negative and the" punishment" is less than the "reward" of over-education. All show that the over-investment in education is reasonable, and if the cost is not taken into account, as for educational investment, the more is better than the less. The result of this study is consistent with the previous research results in Europe and America, which validates the income characteristics of over-education.

Huang Zhiling surveyed the data of the incidence and impact of over- education (Huang Zhiling, Lu Yan, \& Fan Xiaogang, 2010). The study controlled the variables of the individual gender, experience, nature and geography of the enterprises, found when the number of years of education is higher than the standard deviation of the average level of education, the same academic laborers' income is less about $4.9 \%$ than the people who has lower education, which because of excessive education discounted the income of parts of education. However, due to the study uses the mean value method to define the education required for the work and is assumed to be, or otherwise it is 0 , therefore, it is impossible to obtain the return of part of excessive education.

$\mathrm{Wu}$ Xiangrong found that women's education rate of return and return of work required education are higher than men, when it only consider to the impact of gender (Wu Xiangrong, 2007b). On the other hand, the return of men's overworked education is lower than that of women, and "inadequate punishment" is much more than that of women, but relatively speaking, women' lose more than that of men (women lose $4.8 \%$ and $3.9 \%$ of men) when they both suffering over-education; the loss of women is also more than men's $(9.5 \%$ for females and $7.9 \%$ for males) when there is insufficient education.

\section{The Analysis on Problems of Over-Education}

First of all, there are serious measured problems of over-education because of China has no systemic professional catalog dictionary for researchers to refer to and less domestic research using job analysis methods to measure over-education, so the professional coding and education are quite untrustworthy and the mismatch of education is obviously over-estimated. But Bishop also suggested that "over-education may be the result of only some college students receiving low-quality education" (Bishop, 1993), that is, over-education is caused by the decline in the quality of education, and now the level of knowledge and skills of graduate students is lower than the graduations of decades ago. Some people think that higher education expansion reduce the threshold to enter university while the teachers is not keep face, which will doe to the decline of education quality. Beside, the tradition in China's education is "difficult to enter while easy to graduate", there are fewer situations in which students fail to graduate from university, so the quality of education various in different graduations.

Second, it is over utilitarianism when analysis over-education in China. According to the assumption of human capital theory, the return that students get from time, energy and money that put into study are not only in the forms of 
monetary, and there are also in forms of non-monetary, while people trend to utilitarianism as ignoring the non-monetary return will overestimate the incidence of over-education when they analysis over-education. In the discussion of the non-monetary return of education, we cannot ignored the happiness as ignoring the non-monetary gains will overestimate the incidence rate of overeducation. The existing research is usually push forward from the monetary return of education to carry out the study of the impact mechanism, while there are relatively less for the transmission mechanism in non-monetary return of education, especially the discussions of more systematic impacts on the mechanism and impact mechanism of non-monetized return is rarely.

What's more, it is popular for job dis-match among graduations in China. When research the over-education, we consider the different major has homogenization is the default, while it is more possibility for lacking of education but not over-education, which will result in over-education being overestimated.

\section{Conclusion}

As the government stressed the number of talents for a long time, while ignoring the improvement of the quality of education, which leads to the result that the labor market cannot match the output of high educated talents in a short time and the phenomenon of low position with high education. It is not only the developed countries suffering over-education but China has the same problem too. However, the over-education cannot be wiped out completely as people's pursuit of knowledge is not entire utilitarianism and market regulation also takes time, so it is similar to the natural rate of unemployment, and over-education should also have a "natural over-rate", which is reasonable for over-education with the scope of the natural over-rate while the government should involve and guide to avoid over-education when beyond the scope.

There are fewer researches for over-education in China but according to the existed research results, over education in Chins is not much serious compared with what happened in 70s to 90s in western countries. Because of lacking fresh research we don't know what the development of over-education is and there is no standard to measure over-education, and we have no idea of comparison between China and western countries, so there is still a long way to go for researchers to explore over-education in China.

\section{References}

Bishop, J. H. (1993). Over Education. CAHRS Working Paper Series.

Huang Zhiling, Lu Yan, \& Fan Xiaogang. 黄志岭, 逯岩, 㚞小钢. (2010). Empirical Research on the Return Effect of Over-Education 过度教育的收入效应实证研究. Collected Essays on Financial Economics, 6, 16-22.

Li Fengliang, Yue Changjun, \& Houlonglong. 李锋亮, 岳昌君, 侯龙龙. (2009). Signaling Function on Over-Education and Education 过度教育与教育的信号功能. China Economic Quarterly, 2, 570-581.

Ma Wenwu, \& Li Zhongqiu. 马文武, 李中秋. (2016). Investigating of Urban and Rurual Residents's Over-Education in China: Analysis on CHNS Data 中国城乡居民过度教 
育考察: CHNS 数据的经验分析. Innovation, 6, 113-122.

Wei Xin, \& Qin Wanshun. 魏新, 秦宛顺. (1990). Quantitative Analysis of the Influence of Education on the Invisible Labor Input and Production of Large Scale Joint Ventures in China 教育对我国大型联合企业 “无形的劳动投入” 及生产影响的定量分析. Advances in Magnitude \& Techology Economy, 2, 13-23.

Wu Xiangrong, \& Lai Desheng. 武向荣, 赖德胜. (2010). Incidence Rate and Its Impacts of Over-Education-Based on Data in Beijing City 过度教育发生率及其影响因素一 基于北京市数据的分析. Research in Education Development, 19, 36-41.

Wu Xiangrong. 武向荣. (2007a). Phenomenon and Return Effect on the Expansion of Over-Education 教育扩展中的过度教育现象及其收入效应. Peking Normal University Journal, 3, 132-136.

Wu Xiangrong. 武向荣. (2007b). Return Effect on Chinese Over-Education 中国过度教 育的收入效应. Peking University Education Review, 2, 136-146.

Yang Juan, Meng Dahu, \& Yue Changjun. 杨娟, 孟大虎, 岳昌君. (2011). Empirical Research on Risk and Return of Higher Education 高等教育投资风险和收益的实证研 究. Renmin University of China Education Journal, 1, 80-90.

Scientific Research Publishing

Submit or recommend next manuscript to SCIRP and we will provide best service for you:

Accepting pre-submission inquiries through Email, Facebook, LinkedIn, Twitter, etc. A wide selection of journals (inclusive of 9 subjects, more than 200 journals)

Providing 24-hour high-quality service

User-friendly online submission system

Fair and swift peer-review system

Efficient typesetting and proofreading procedure

Display of the result of downloads and visits, as well as the number of cited articles

Maximum dissemination of your research work

Submit your manuscript at: http://papersubmission.scirp.org/

Or contact chnstd@scirp.org 